\title{
'Regulation' of gutless annelid ecology by endosymbiotic bacteria
}

\author{
O. Giere $^{1}$, N. M. Conway ${ }^{2}$, G. Gastrock ${ }^{1}$, C. Schmidt ${ }^{1}$ \\ ${ }^{1}$ Zoological Institute, University of Hamburg, Martin-Luther-King-Platz 3, D-2000 Hamburg 13, Germany \\ ${ }^{2}$ Woods Hole Oceanographic Institution, Coastal Research Lab, Woods Hole, Massachusetts 02543, USA
}

\begin{abstract}
In studies on invertebrates from sulphidic environments which exploit reduced substances through symbiosis with bacteria, experimental ecological results are often underrepresented. For such studies the gutless oligochaete Inanidrilus leukodermatus is suitable due to its mobility and local abundance. It contains endosymbiotic sulphur-oxidizing bacteria and inhabits the sediment layers around the redox potential discontinuity (RPD) with access to both microoxic and sulphidic conditions. By experimental manipulation of physico-chemical gradients we have shown that the distribution pattern of these worms directly results from active migrations towards the variable position of the RPD, demonstrating the ecological relevance of the concomitant chemical conditions for these worms. Their distributional behaviour probably helps to optimize metabolic conditions for the endosymbiotic bacteria, coupling the needs of symbiont physiology with host behavioural ecology. The substantial bacterial role in the ecophysiology of the symbiosis was confirmed by biochemical analyses (stable isotope ratios for C and $\mathrm{N}$; assays of lipid and amino acid composition) which showed that a dominant portion of the biochemical fluxes in the symbiosis is bacteria-based. It appears that the distributional and nutritional ecology of the gutless annelids is strongly influenced by their symbiosis with sulphur bacteria.
\end{abstract}

\section{INTRODUCTION}

Many symbioses between invertebrates and chemoautotrophic bacteria have been documented at the structural, and to some extent physiological and microbiological, levels (for reviews see Cavanaugh 1985, Southward 1987). However, the ecological effects resulting from this close partnership between bacteria and animal host are generally less recognized.

Thiobiotic animals, both meio- and macrobenthic, tend to live around the redox chemocline (Powell \& Bright 1981, Powell et al. 1983, Scherer 1985, Southward 1987, Meyers et al. 1987, 1988, Ott \& Novak 1989). In this preferred layer they have access to mild concentrations of both reduced sulphur and oxygen. Initial analyses of populations of the gutless tubificid Inanidrilus (Phallodrilus) leukodermatus by Giere et al. (1982) suggested that this pattern is also found in bacteria-symbiotic annelids from sulphidic sediments. In this paper we describe the results of 3 different, but complementary, approaches to studying the ecological coupling between endosymbionts and host:

(1) Field ecology. The distributional ecology of the worms was determined by further investigation of their vertical field distribution.
(2) Experimental ecology. Inanidrilus leukodermatus is one of the few members of the sulphide fauna that is suitable for experimental ecological work due to its sufficient size, high mobility, locally rich populations and its well-documented scientific background (Giere \& Langheld 1987, Giere 1989). Its symbiotic endobacteria are chemoautotrophs which preferentially oxidize thiosulphate in order to obtain their metabolic energy. The storage of rich bacterial reserve substances (polythionates and polyhydroxy butyric acid) makes the worms usually appear shiny white (Giere et al. 1988b). Only rarely, i.e. in the oxygenated surface horizons, are worms greyish-transparent. Hence, the position of the worms within the steep chemical gradients of the vertical sand column should have a marked influence on either the production or consumption of these storage substances which is evidenced by their appearance as 'white' or 'pale' worms (Giere et al. 1988b). By manipulation of the oxygen and reduced sulphur conditions in the sediment it was tested how the symbiotic worms adjust to redox and sulphide gradients. A varying supply of reduced sulphur should influence both the appearance of the worms and their distributional pattern.

(3) Biochemical analysis of the nutritional interac- 
tions between bacterial symbionts and annelid host. The role of the bacterial symbionts as a nutritional source for their gutless hosts is difficult to assess because of the intricate structural and physiological interactions between the symbiotic partners (Giere \& Langheld 1987). Analysis of biochemical composition and measurement of stable isotope ratios ( $\mathrm{C}$ and $\mathrm{N}$ ) can give indications on the relevance of bacterial chemoautotrophy for the diet of the worms (Conway \& McDowell Capuzzo 1990a).

\section{MATERIALS AND METHODS}

Most field and experimental studies were done in summer 1989 in the laboratories of the Bermuda Aquarium, Museum and Zoo, close to the sample station in Flatts Inlet, the narrow passage from the sea to Harrington Sound, Bermuda. We obtained fresh worms, original sand and seawater directly from the sampling site. All samples were taken by SCUBA divers from depths between 2 and $4 \mathrm{~m}$. Data from vertical cores taken with essentially identical methods at the same location during former stays in Bermuda are included in the results and discussion.

Vertical cores from the sublittoral sediment in Flatts Inlet (Bermuda) were taken by SCUBA divers to study the microdistribution of the worms in relation to the pore water conditions (perspex corer of $5 \mathrm{~cm}$ internal diameter and $30 \mathrm{~cm}$ length). Cores were subdivided immediately after retrieval, and split into 2.5 or $3 \mathrm{~cm}$ fractions, the redox values were recorded and the worms quantitatively decanted and counted upon return to the laboratory.

Sulphide content in the pore water was measured in 10 vertical series ( 3 in 1981, 6 in 1986 and 1 in 1989). For determination of dissolved sulphide in the natural sediment ( $\mathrm{pH} 7.9$ to 8.5 ), undisturbed pore water samples were collected by divers using small hypodermic syringes (Giere et al. 1982, Howes \& Wakeham 1985). In 1989, spectrophotometric analysis (modified after Cline 1969) could not be done in Bermuda, consequently the sulphide, precipitated by alkaline zinc acetate, was filtered through Millipore filters (pore width $0.2 \mu \mathrm{m})$. These filters were kept in Millipore special filter jars in the refrigerator until return to the laboratory where the precipitate was dissolved for further photometric analysis by addition of $5.5 \mathrm{~N} \mathrm{HCl}$. Using this method the amount of sulphide in the samples may have been slightly underestimated due to immediate oxidation during handling of the syringe, precipitation loss and bacterial degradation. The resulting data, therefore, represent conservative values.

Porewater for analysis of the amino acids was sampled by a 'pore water lance' (Giere et al. 1988a).
Manipulation of the redox potential discontinuity (RPD) depth. Migration experiments were designed to investigate the vertical distribution of worms, allowing the setting of the RPD layer in a given horizon of a sand column. Perspex tubes (diam. $2.6 \mathrm{~cm}$, length $15 \mathrm{~cm}$ ) were filled with reduced, gray sand or oxygenated, white sand, and a sharp redox-cline was set up at a given horizon. The bottom and top of each core was covered with nylon gauze ( 10 to $20 \mu \mathrm{m}$ mesh size). After insertion of 20 active, undamaged worms into a chosen $3 \mathrm{~cm}$ layer, the cores were placed in a small glass tank which contained a reduced sediment layer at the bottom and an oxygenated surface. The top of the tube rose above the sediment and aerated seawater was allowed to flow around it.

As a generalized indication for oxygenated or reduced conditions (Giere et al. 1988a) in the experimental cores, redox values were recorded in every $3 \mathrm{~cm}$ layer when fractionating the sediment core at the end of each experimental run (mostly after $72 \mathrm{~h}$ ). By subsequent careful decantation of the 5 resulting subsamples (about $16 \mathrm{~cm}^{3}$ each) the new position of the worms was evaluated (retrieval rate mostly 90 to $100 \%$ ) and recorded with respect to the monitored redox value. A few cores from first experiments in 1986 were included in the evaluation. Regrettably, within the time available, not all experiments could be based on sufficient numbers of replicates for reliable statistical evaluation (see 'Results').

Experimental pale/white conversion of worms as a result of variations in nutrient supply of the symbiotic bacteria was performed in small experimental boxes (about $2 \mathrm{~cm}^{3}$ ) filled with original sediment and water. After insertion of 5 worms, each box was capped with nylon gauze of 10 to $20 \mu \mathrm{m}$ mesh size and implanted into the sulphidic or oxic sand layers of the same glass tanks used for the migration experiments. Average duration of each experiment was $72 \mathrm{~h}$ before the worms were retrieved and their color inspected. Similar experiments performed during former stays on Bermuda were incorporated into the evaluation.

Measurement of stable isotope ratios (C and N). Airdried worms, sampled in October 1989 in Bermuda, were analyzed in Woods Hole (for detailed methods see Conway et al. 1989). Due to the limited amount of material, each determination was based on one pooled worm population (about 100 specimens); thus, the values obtained are preliminary.

Lipids were analysed chromatographically after conversion to fatty acid methyl esters following the methodology of Conway \& McDowell Capuzzo (1990b). The values given here are averages of 3 extractions of pooled worms.

Amino acid composition of the worms was measured after formation of phenylcarbamyl derivatives (modified 
after Yang \& Sepulveda 1985). Determinations were based on 2 parallel subsamples of pooled, dried worms.

\section{RESULTS}

\section{Vertical field distribution of chemical gradients and worms}

\section{Physiographical factors}

Except for the top $2.5 \mathrm{~cm}$ layer the calcareous sand was fairly fine (Md in the range of $150 \mu \mathrm{m}$, lower and upper quartiles at 91 and $430 \mu \mathrm{m})$. The sorting coefficient of 2.1 characterizes it as 'very poorly sorted' indicating the typical situation in calcareous sands with much fine detritus and shell debris clogging the interstices. The top layer, with its coarse shell particles $(\mathrm{Md}=$ 528) covering this fine material, prevents the sediment from being eroded, but apparently also reduces penetration of oxygenated water despite the strong tidal currents. This sedimentary situation was reflected by the gradients of redox potential and sulfide: average Eh values ranged from $+250 \mathrm{mV}$ in the uppermost subsample $(3 \mathrm{~cm}$ layer $)$ to $\mathrm{ca}-150 \mathrm{mV}$, with the discontinuity usually at depth 7 to $8 \mathrm{~cm}$. However, rather than a sharp boundary, the change from oxic to reduced conditions was mostly gradual. This was paralleled by the transition zone from whitish to a greyish-dark coloration of the sediment due to formation of iron sulphides. It usually coincided well with the recorded RPD-threshold.
The layers with negative redox potential beyond about - $50 \mathrm{mV}$ smelled distinctly of $\mathrm{H}_{2} \mathrm{~S}$. Values for sulphide in the pore water of the deeper layers showed large variations between samples depending probably on the local sediment structure and exposure to the water current. Their maximum values (in depths of 15 to $20 \mathrm{~cm}$ ) were in the range of about $200 \mu \mathrm{mol} \mathrm{S}=$. In the layers preferred by the worm population (see below), the sulphide content was far below these extreme values and usually lay in the range 5 to $50 \mu \mathrm{mol} \mathrm{S}=$

\section{Annelid distribution}

In all vertical cores the populations of Inanidrilus leukodermatus centered around, or somewhat below, the RPD layer with a steep decrease towards the oxic subsurface layer and the sulphidic depth horizons. This is shown in Fig. 1, a combined evaluation of 5 vertical cores. Although taken from just one locality (ca $3 \times 2$ $\mathrm{m}^{2}$ ), the density of worms per core was variable resulting in high standard deviations particularly around the RPD layer.

If worm numbers from all samples are compiled and calculated in a polynomial regression against either sediment depths (Fig. 2) or redox values (Fig. 3) respectively, the result in both cases is a significant relation. The preferred depth is again shown to be between 5 and $7 \mathrm{~cm}$ and at redox values (Eh) between +50 and $-50 \mathrm{mV}$, i.e. positioned symmetrically around the RPD threshold. Also the Spearman-Rank Test showed a

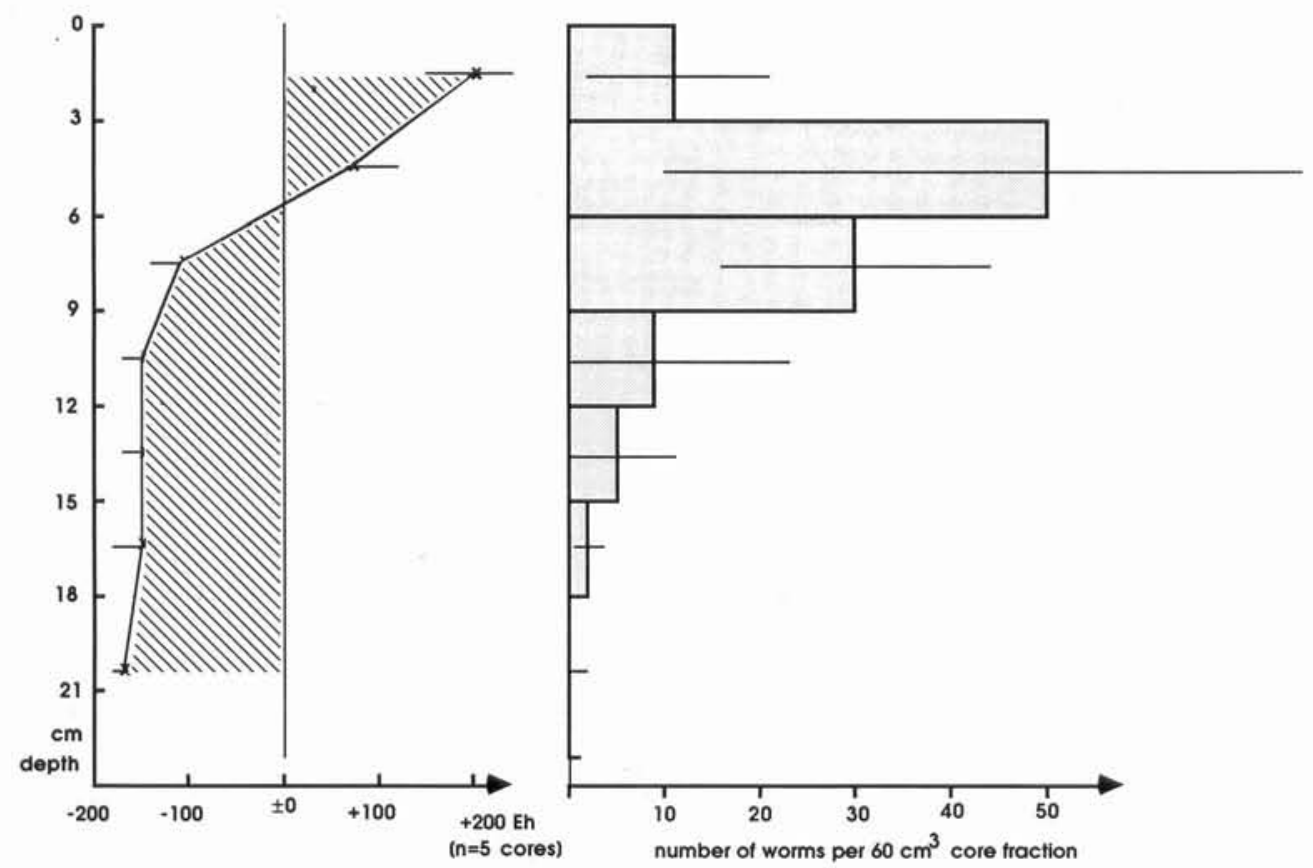

Fig. 1. Vertical pattern of redox potential (left) and distribution of Inanidrilus leukodermatus (right) in the sampling area; compilation of 5 parallel cores 


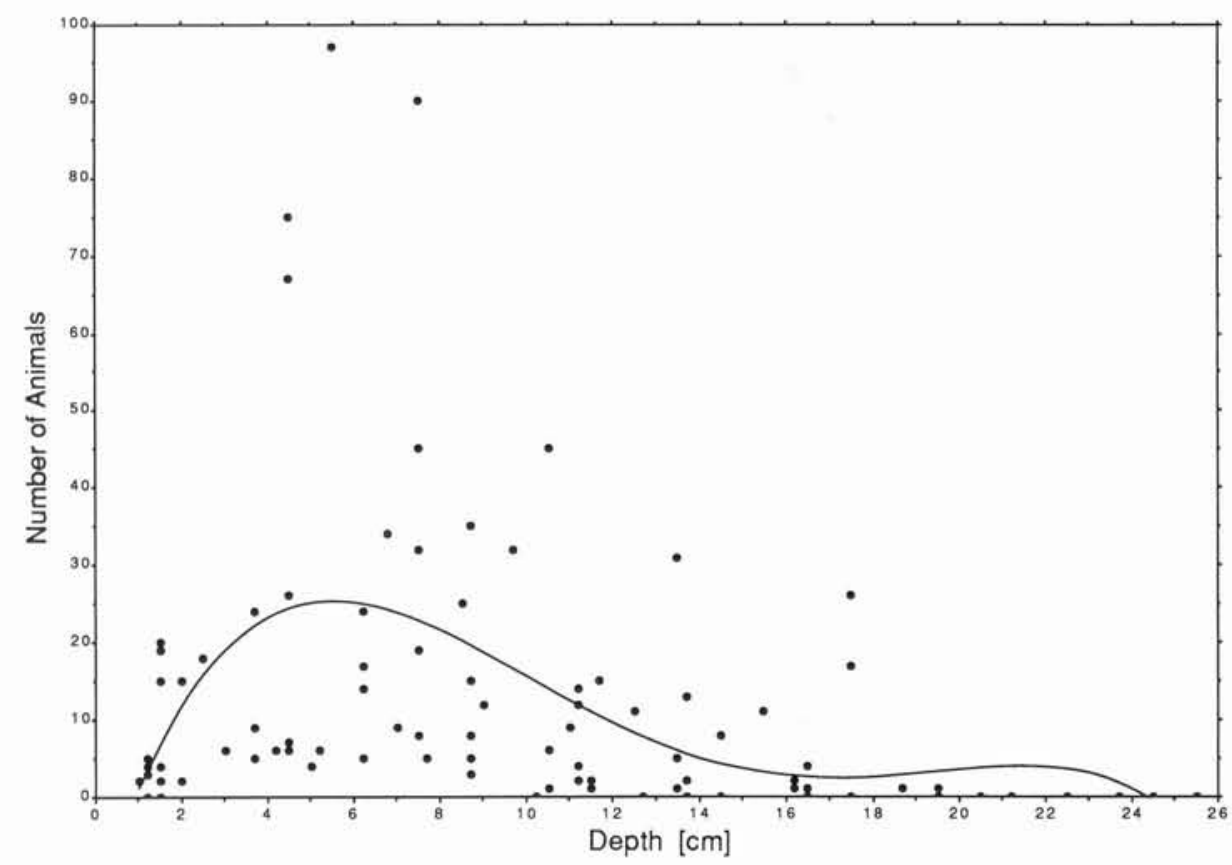

Fig. 2. Polynomial regression curve of sediment depth vs worm distribution in the field indicating preferred occurrence around $5 \mathrm{~cm}$ depth; compilation of 5 parallel cores. Equation of line:

$$
\begin{aligned}
y= & 13.962+17.455 x \\
& -2.503 x^{2}+0.127 x^{3} \\
& -2.155 \times 10^{-3} x^{4}
\end{aligned}
$$

clearly significant relationship between worm number per subsample and these parameters $(p=0.01$ for redox values, $\mathrm{p}=0.001$ for depths).

Experimental variation in nutrient supply for symbiotic bacteria

White worms. If kept for $72 \mathrm{~h}$ in oxygenated sediment, the colour of the worms changed gradually and became completely greyish-pale and rather transpa- rent ( $\mathrm{n}=15$ replicate boxes with 5 worms each). The worms stayed fully active and showed no signs of sluggishness during this experimental period; only the supply of light-refractile (bacterial) reserve substance apparently had decreased (for quantitative data see Giere et al. 1988b). In some longer-term experiments with conditions manipulated to alternate from oxic to reduced and back to oxic, the annelids reversed their appearance from white to pale and back to white.

In controls, white worms from the same sample unit, kept for the same period of time in highly sulphidic

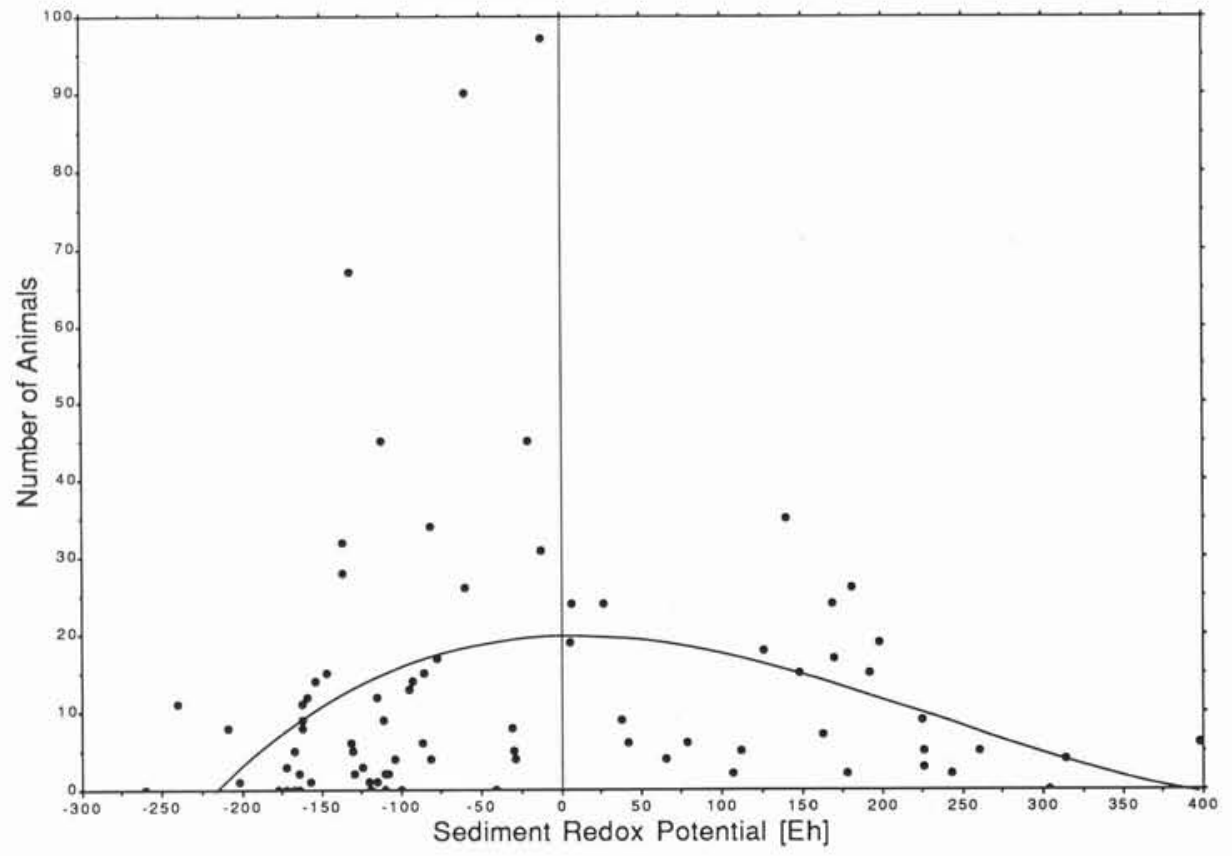

Fig. 3. Polynomial regression curve of sediment redox conditions vs worm distribution in the field indicating preferred occurrence around the redox discontinuity layer; compilation of 5 parallel cores. Equation of line:

$y=19.76+4.265 \times 10^{-3} x$

$$
-3.1210 \times 10^{-4} \mathrm{x}^{2}
$$


sediment ( $>300 \mu \mathrm{mol} \mathrm{S}=$ ), stayed fully white. However, under these conditions, some of the worms were always found dead or sluggish, albeit still white. The worms are less adapted to longer-term exposure to anoxia and sulphide. Under these conditions, the endosymbiotic bacteria did not alter their supply of reserve substances, indicated by the persisting white colour of the worms.

Pale worms. Pale worms from oxygenated sediment, inserted into sulphidic sediment, usually turned white after $72 \mathrm{~h}(\mathrm{n}=15$ replicate boxes with 5 specimens each). In controls, where the worms remained for $72 \mathrm{~h}$ under oxygenated conditions, they always stayed pale, but about $30 \%$ became sluggish or died.

These results, obtained in small boxes, were confirmed in the larger tubes set up for migration experiments (see below). Also here, the worms' coloration changed depending on the experimentally induced oxic/sulphidic character of the ambient sediment.

Correspondingly, under natural conditions (i.e. in vertical cores taken in the field) the appearance of the worms is not uniform. Most specimens are clearly white, however, a small part of the population (about $5 \%$ ) is found pale. Since the appearance of the worms apparently mirrors the supply of sulphide and oxygen, this field observation indicates vertical migrations along the steep chemical gradient system.

\section{Migration experiments}

This set of experiments was designed to experimentally verify the assumption that worm migrations are dependent on the chemical regime.

Redox and sulphide gradients in the test tubes

The redox potential in the reduced sand we used was about - $210 \mathrm{mV}$ Eh, that of its oxygenated coun- terpart was recorded as $+230 \mathrm{mV}$ Eh. Under the experimental conditions described above, redox potentials in the various layers of the artificial sand column stayed relatively stable throughout the duration of the experiment, sometimes with a slight upward drift of the RPD layer which usually clearly coincided with the characteristic colour change of the sand grains from whitish to gray. Sulphide content in the reduced sediment used for the experiments was around $300 \mu \mathrm{M} \mathrm{S}=$ indicating complete anoxia. The development of sulphide concentrations in the experimental tubes with the RPD positioned at $13 \mathrm{~cm}$ depth was followed in a time course series of 6 parallel tubes over the duration of $96 \mathrm{~h}$. Between 24 and $72 \mathrm{~h}$ (the usual end point of the experiments) sulphide in the bottom $2 \mathrm{~cm}$ of the tubes remained relatively stable around a median concentration of $260 \mu \mathrm{M} \mathrm{S}=$ with variations between 240 and $300 \mu \mathrm{M} \mathrm{S}=$. This maintenance of the redox and sulphide regime throughout the experiments underlines the reliability of the experimental set-up.

Reaction of worms to changes in redox conditions

All experimental runs were tested statistically for randomness of the central distributional trend (Friedman test). All samples clearly showed a non-random trend in their distribution. The various experimental runs (each lasting for about $72 \mathrm{~h}$ ) can be grouped into 4 categories:

\section{White worms}

- The RPD was established in about $13.5 \mathrm{~cm}$ depth, 1.5 $\mathrm{cm}$ above the bottom of the tube, with the worms inserted at the top (Fig. 4). After $3 \mathrm{~d}$, almost $70 \%$ of the worms were regularly found in the bottom layers around the RPD ( $n=10$ experimental runs, differences of mean values highly significant; $p=0.001$ for a non-random distribution).
Fig. 4. Migration experiments with redox discontinuity (RPD) set at lower end of the tube and (white) worms inserted at the top: aggregation in deeper layers

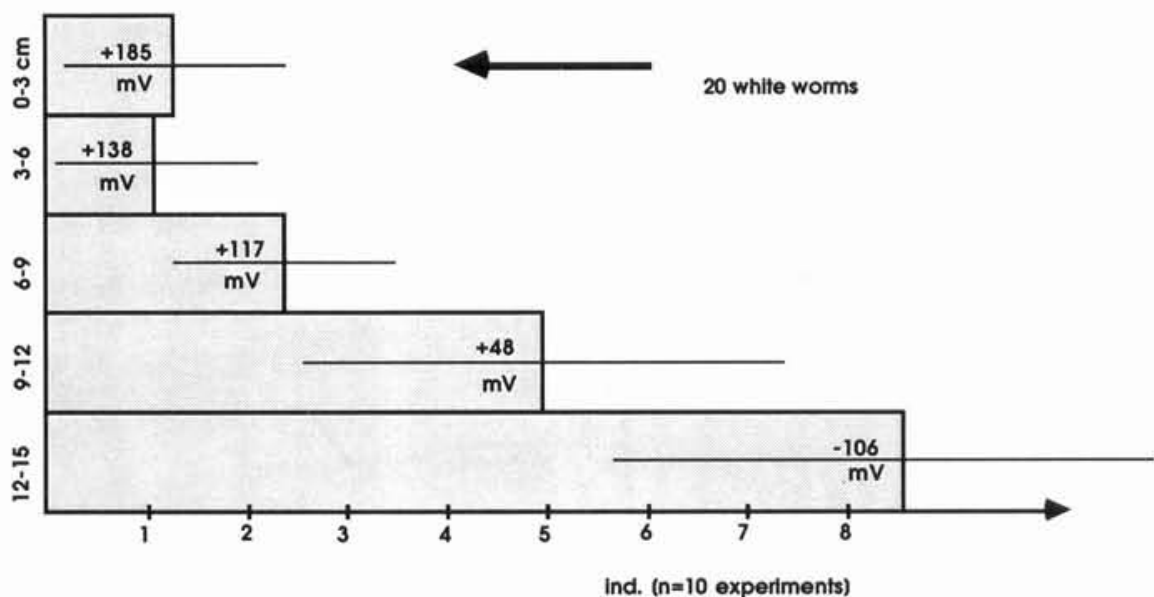




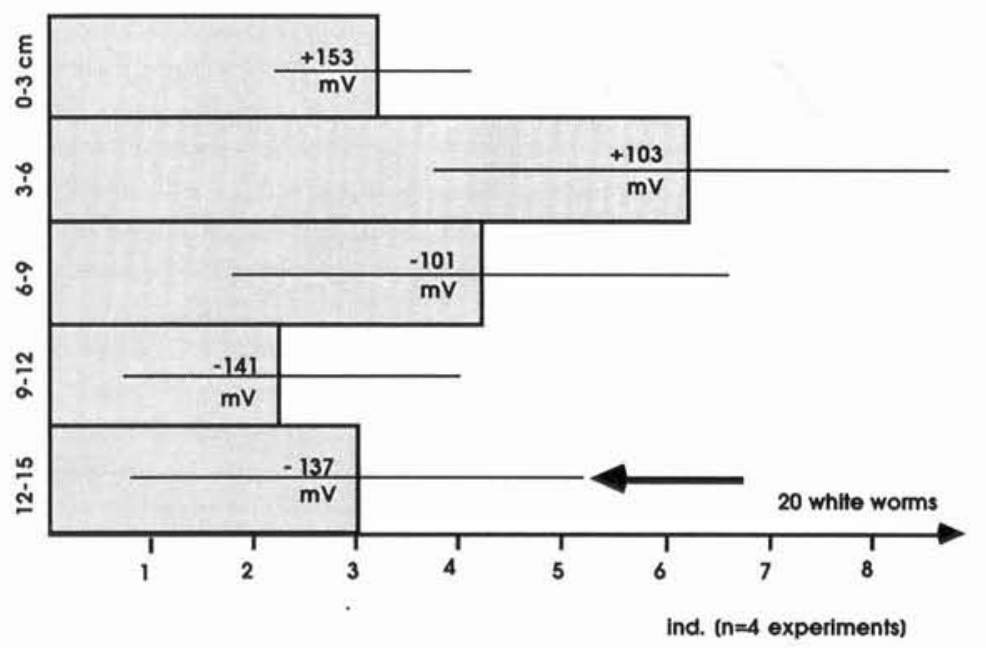

Fig. 5. Migration experiments with RPD set in centre of the tube and (white) worms inserted at bottom: aggregation in middle layers

- Setting the RPD in a median position (6 to $7 \mathrm{~cm}$ ) and inserting the worms at the bottom resulted in an accumulation of worms in the middle of the tube (Fig. 5) with a more gentle decrease of worm numbers towards top and bottom ends ( $\mathrm{n}=4$ runs, mean values of middle layers significantly different at $90 \%$ level from those of top and bottom).

- A similar, but more pronounced, distribution pattern became established if the RPD was positioned close to the top end of the tube (in the $3 \mathrm{~cm}$ horizon) with the worms again starting from the bottom. $90 \%$ of the worms were found in the 2 upper fractions with a clear maximum in the moderately reduced, low sulphidic horizon close to the RPD (Fig. 6). Due to the low number of runs $(n=2)$, we could not calculate the statistical significance; however, the migration pattern is clear.

Pale worms (generated by leaving 'whites' for about 24 to $48 \mathrm{~h}$ in oxygenated sediment).

- Again the RPD was established in about $13.5 \mathrm{~cm}$ depth, $1.5 \mathrm{~cm}$ above the bottom of the core, while the worms were inserted at the top (Fig. 7). After $3 \mathrm{~d}$,
$80 \%$ of the worms were regularly found near the bottom around the RPD ( $\mathrm{n}=5$ experimental runs, differences of mean values in bottom layers highly significant from those in 3 uppermost layers; $\mathrm{p}=$ 0.005 for a non-random distribution).

Controls. Tubes which, at the end of the experimental period, were totally oxic or totally sulphidic served as controls. Here, the worms were approximately evenly distributed without any recognizable trend.

These 4 groups of experiments suggest that it is the specific environmental condition at the RPD which attracts the worms. This was confirmed by additional experimental runs in which the worms were inoculated directly into the redoxcline. The worms stayed here for the duration of the experiment, exhibiting no migration.

In experiments lasting less than about $60 \mathrm{~h}$, only a migratory trend in the direction towards the RPD was discernible, but a marked maximum never developed over the short time period. In experiments lasting only 12 to $24 \mathrm{~h}$, no clear pattern was evident even when a constant RPD layer was maintained.

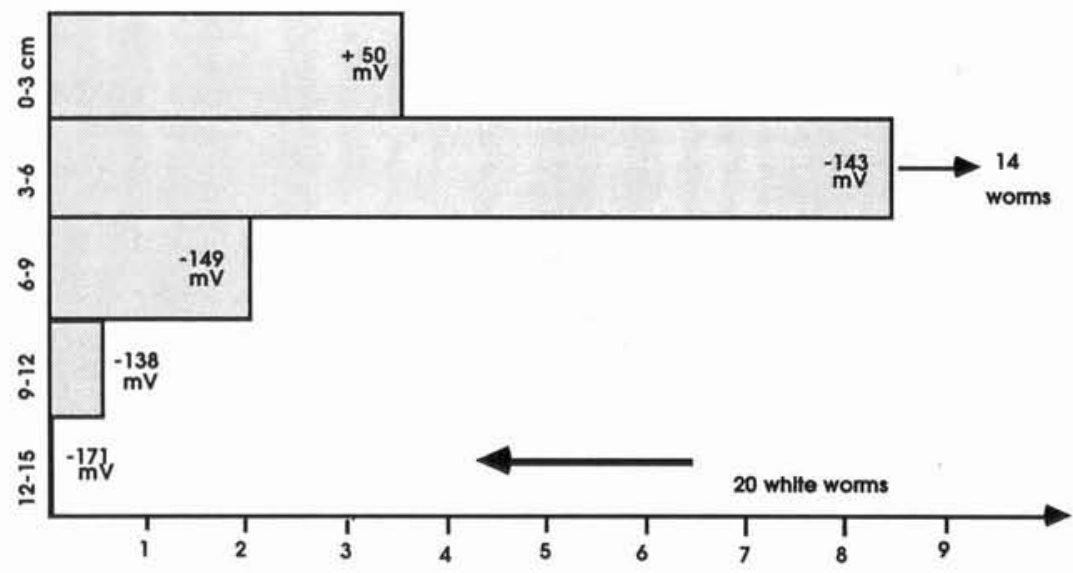

Ind. ( $\mathrm{n}=2$ experiments)
Fig. 6. Migration experiments with RPD set under the surface of the tube and (white) worms inserted at bottom: aggregation in top layers 
Fig. 7. Migration experiments with RPD set at lower end of the tube and (pale) worms inserted at top: aggregation in deeper layers

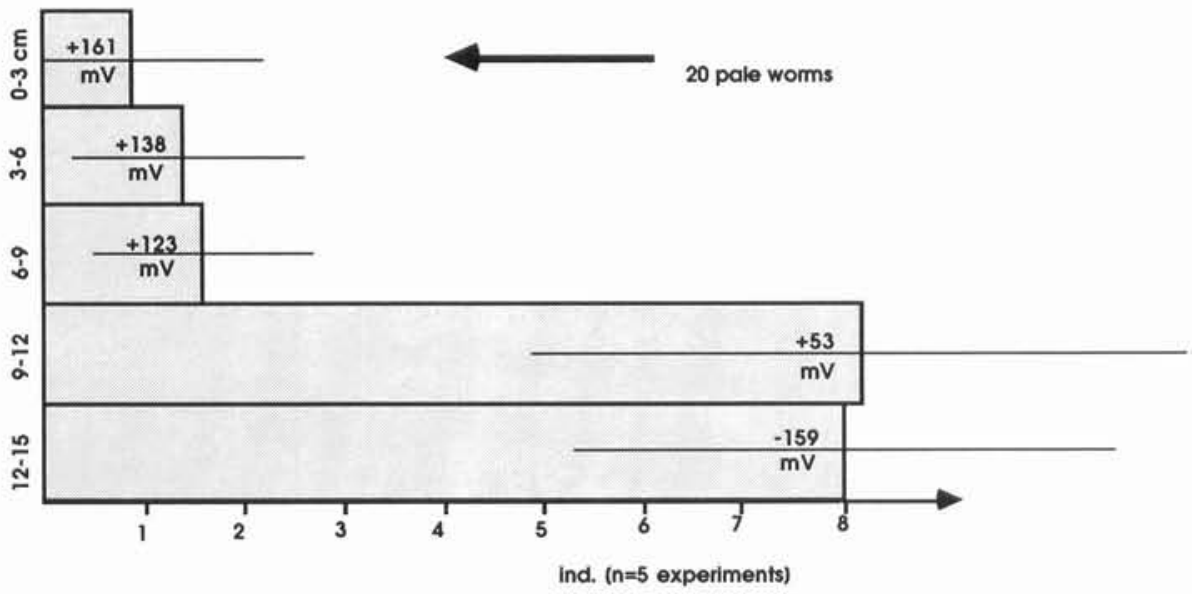

\section{Stable isotope ratios}

In Inanidrilus leukodermatus the symbiotic bacteria are intimately integrated in the cuticle/epidermis complex and separation of bacteria-containing and bacteria-free tissues is not possible. Thus, the total worm homogenate had to be measured. The resulting $\delta^{13} \mathrm{C}$ value $\left({ }^{13} \mathrm{C}:{ }^{12} \mathrm{C}\right.$ ratio) was - $26.0 \%$; the corresponding $\delta^{15} \mathrm{~N}\left({ }^{14} \mathrm{~N}:{ }^{15} \mathrm{~N}\right.$ ratio) was - $1.4 \%$.

The lipid composition of Inanidrilus leukodermatus tissue (Fig. 8) was dominated by the 5 fatty acids 16:0, $16: 1 \omega 7,18: 0,18: 1 \omega 7$ and 18:1 19 , which accounted for $77.9 \%$ of the total fatty acid pool. Cis-vaccenic acid (18:1 107$)$ made up $43.0 \%$, while the other dominating fatty acids, palmitic acid (16:0) and stearic acid (18:0) accounted for $13.5 \%$ and $9.3 \%$ respectively.

Among amino acids, glycine, alanine, valine and leucine accounted for $56 \%$ of total amino acids.

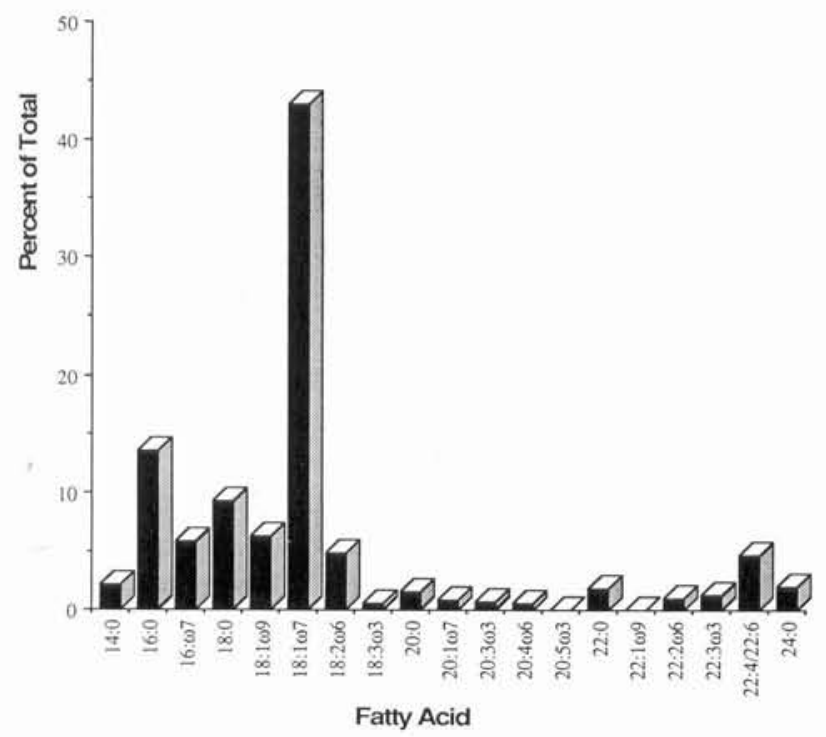

Fig. 8. Inanidrilus leukodermatus. Lipid composition calculated as percentage of fatty acids in total pool. Note dominance of bacteria-derived 18:1 $1 \omega 7$ (cis-vaccenic acid)
Although in marine organisms these are generally the most common amino acids, it is noteworthy that in our symbiotic worms the whole set of 'essential' amino acids was present (Fig. 9, Table 1), even those which They amounted to about $50 \%$ of total. (Tryptophan has not been recorded here, but this amino acid is often destroyed during acid hydrolysis.)

\section{DISCUSSION}

\section{Field distribution and migration experiments}

Under natural conditions, the redox chemocline is a complicated and dynamic 'landscape' (Ott \& Novak 1989) representing, in calcareous sands, a rather gradual transition zone from positive to negative val-

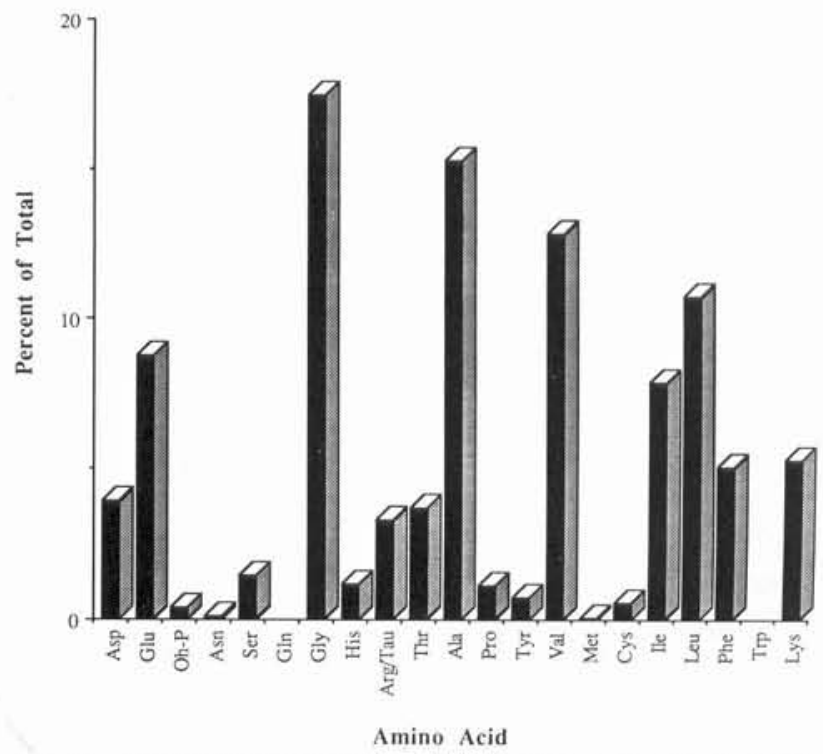

Fig. 9. Inanidrilus leukodermatus. Amino acid composition calculated as percentage of total pool. Note presence of all essential amino acids. (For methodological reasons Tryptophan not measured) usually cannot be synthesized by the eukaryotic host. 
Table 1. Inanidrilus leukodermatus. Amino acid composition: tissue homogenate in contrast to pore water from sediment in sampling area (obtained by different analytical methods)

\begin{tabular}{|c|c|c|c|}
\hline Amino acid & \multicolumn{2}{|c|}{ Worm tissue } & $\begin{array}{c}\text { Pore water, } 5 \mathrm{~cm} \text { depth } \\
\% \text { of total }\end{array}$ \\
\hline Aspartic acid & 144 & 3.9 & 10.6 \\
\hline Glutamic acid & 322 & 8.8 & 46.1 \\
\hline B-Glutaric acid & & & 2.5 \\
\hline Hydroxy-proline & 15 & 0.4 & $\cdot$ \\
\hline Asparagine ${ }^{a}$ & 5 & 0.1 & 5.2 \\
\hline Serine $\mathrm{e}^{\mathrm{b}}$ & 54 & 1.5 & 1.6 \\
\hline Glutamine $^{a}$ & 0 & 0 & 13.2 \\
\hline Glycine & 640 & 17.5 & 2.3 \\
\hline Histidine & 43 & 1.2 & 1.1 \\
\hline Taurine/arginine/tyrosine & 149 & 4.1 & 1.9 \\
\hline Threonine $^{\mathrm{b}}$ & 136 & 3.7 & \\
\hline Alanine & 560 & 15.3 & 6.8 \\
\hline$\beta$-Alanine & & & 2.0 \\
\hline Proline & 41 & 1.1 & \\
\hline Valine/methionine & 475 & 12.9 & 2.8 \\
\hline Cystine/cysteine & 21 & 0.6 & \\
\hline Isoleucine & 290 & 7.9 & 0.8 \\
\hline Leucine & 396 & 10.8 & 0.8 \\
\hline Phenylalanine & 186 & 5.1 & 1.4 \\
\hline Tryptophan ${ }^{\mathrm{b}}$ & 0 & 0 & \\
\hline Lysine & 193 & 5.3 & 0 \\
\hline Others & & & 0.9 \\
\hline Total & 3670 & 100 & 100 \\
\hline
\end{tabular}

ues. Thus, for sulphur bacteria the area where microoxic and mildly sulphidic conditions overlap is favourably wide. Movement towards this horizon of optimal factorial combinations and mobility within this network seems particularly important in these types of symbiotic associations as sulphur bacteria prefer changing gradients of sulphur compounds and oxygen (Jørgensen \& Revsbech 1983, Jannasch pers. comm.). Here, even micro-electrodes are too insensitive to measure the ever-fluctuating redox conditions in due resolution and detail (Revsbech pers. comm.). Thus, our Eh recordings give only relative 'background information' about the general oxic conditions, and should not represent a basis for quantitative calculation of fluxes.

Thiobiotic animals adjust in different ways to the preferred conditions at the chemocline. Less mobile symbiotic animals like bivalves or the sessile pogonophorans may accomodate the range of reduced, sulphidic and low oxic conditions by morphological or physiological adaptations (ventilation currents, tubes and siphons, specific properties of coelomic fluid and blood; see Arp et al. 1984, Cavanaugh 1985, de Burgh 1986, Dando et al. 1986, Reid \& Brand 1986, Powell \& Arp 1989). Small meiobenthic thiobiota, however, can actively move along the steep chemical gradients around the RPD adjusting themselves to the optimal position in this temporally and locally much changing zone (Giere et al. 1982, 1984, Powell et al. 1983, Fox \& Powell 1987, Meyers et al. 1987). Meyers et al. (1988) showed the prompt response of various meiobenthic thiobiota to experimentally fluctuating water changes with subsequent changes in oxic and sulphidic gradients. Ott \& Novak (1989), in preliminary experiments with thiobiotic nematodes, found a corresponding positive reaction to the conditions around the redox cline.

Our experimental studies provide direct evidence to show that the depth of the RPD layer controls the distribution of thiobiotic animals. Fluctuations in the depth distribution of the annelids are more related to the changing location of the oxic/anoxic interface of the sediment than to the actual depth per se.

Despite this attractiveness of the RPD layer, a significant portion of the population is regularly found also in the completely anoxic deeper horizons. This specific distribution pattern not only underlines the considerable tolerance of Inanidrilus leukodermatus to anoxia and hydrogen sulphide (Giere et al. 1982, Giere et al. 1988b), it also explains observations from enclosure experiments: pale worms, inoculated into completely anoxic sand with high concentrations of hydrogen sul- 
phide, turned white indicating that the bacteria managed to build up their metabolic reserves without any access to oxygen.

From this it can be concluded that the uptake of reduced sulphur compounds and their oxidation do not necessarily occur simultaneously. The actual uptake of reduced sulphur seems at least temporarily and partially possible in complete anoxia in those layers with rich supply of reduced substances. It will, of course, later be followed by the necessary binding of oxygen in the upper, microoxic sediment layers in order to obtain the energy needed. This would explain the overall preference of the worms for the RPD layer.

Temporal and spatial partitioning of sulphide and oxygen supply has also been suggested by Reid \& Brand (1986) for the symbiotic bivalve Solemya reidi and for meiofauna by Meyers et al. (1987), who suggested that most of daily metabolism in thiobiotic species must take place in an oxygen-free environment so that oxygen, if required, must be obtained by migratory behavior plus an oxygen storage system'. The vertical distribution of thiobiotic nematodes also indicates separated uptake and metabolization of reduced substances. Ott \& Novak (1989) showed a maximum around the RPD layer; however, they often found another aggregation in the anoxic depths (pers. comm.).

The attractivity of the RPD layer for Inanidrilus leukodermatus (and for many other thiobiotic animals) in contrast to 'normal' oxibiotic meiobenthos raises the question as to which factor might act as a trigger directing animals along a gradient. It is conceivable that the complicated interdependence between $\mathrm{pH}$ and $\mathrm{CO}_{2}$ values in the redox chemocline (Gardner 1973, Böttcher \& Strebel 1985, Gardner et al. 1988) could be an important aspect. 'Small increases in $\mathrm{pH}$ would substantially increase flux and metabolic rate [of HS] while simultaneously decreasing tissue sulfide concentration' (Powell 1989, p. 922). Both increasing alkalinity towards anoxic depths (Gardner 1973) and a general importance of $\mathrm{pH}$ effects on the annelid metabolism (Weber 1978) have been documented.

If a system exists to 'guide' the worms to the optimal bacterial growth conditions, it is surprising that it takes about $3 \mathrm{~d}$ to yield clear distributional patterns considering (1) the length and motility of the worms (as observed in Petri dishes) and (2) the fact that it is a high turnover bacterial metabolism which seems to underly the migrations. However, the chemical microgradients in the sediment column are not only directed vertically. Thus, if undisturbed, the worms may migrate only relatively little in a single direction. Moreover, these oligochaetes might also clump together for a while after insertion, an artifact found in studies on other positively thigmotactic annelids.
With pale worms, even longer times were needed to obtain clear migration patterns and scatter was higher than in white worms. These 'stressed' pale worms (Giere et al. 1988b) showed a low $\mathrm{CO}_{2}$ uptake capacity despite an ample supply with thiosulphate (Giere et al. 1988b). Uptake rates of $\mathrm{CO}_{2}$ in Inanidrilus leukodermatus were measured over up to $6 \mathrm{~h}$ (Giere et al. $1988 \mathrm{~b})$. It is conceivable that the formation of reserve substances and their re-utilization proceeds in correspondingly slow processes, so that the worms' reaction to the lack of reduced sulphur is much retarded.

\section{Biochemical analyses}

The analysis of stable isotope values has become an important method of studying trophic interrelationships between animals (Rounick \& Winterbourn 1986 , Peterson \& Fry 1987), particularly where chemosynthetic bacteria are an important nutrient source and conventional nutritional studies impossible. Consequently, stable isotope ratios are of special relevance in studies on animals with symbiotic bacteria (Spiro et al. 1986, Southward 1987, Conway et al. 1989), since their food source is often largely based on chemosynthetic primary producers. In the case of the gutless oligochaetes, the only trophic pathway beside direct transfer from their endobacteria is transepidermal uptake of dissolved organics from the ambient porewater. This has been documented to be an important food source in annelids (Stephens 1975) including Inanidrilus leukodermatus (Liebezeit et al. 1983, Giere et al. 1984). However, the position of the symbiotic bacteria as a 'mantle' around the annelid's inner tissue suggests that a significant part of this uptake is in fact due to the bacteria and only to a lesser extent due to direct incorporation by the worm.

We have shown in earlier electron-microscope studies that the worms receive dissolved metabolic products and particulate cell material from their symbiotic bacteria (Giere \& Langheld 1987). The stable isotope ratios of Inanidrilus leukodermatus now further demonstrate substantial utilization of bacterial biomass and metabolic products by I. leukodermatus. Measurements from micrographs and the application of a calculation method used by Conway et al. (1989) ('2-source mixing model') encouraged us to quantify this delicate interaction. The endosymbionts account for about $25 \%$ of the annelids' volume (Feller \& Warwick 1988). This value even takes into account the scarcity of bacteria in the preclitellar body region. In order to calculate the contribution of the bacterial endosymbionts to the carbon budget of $I$. leukodermatus, a $\delta^{13} \mathrm{C}$ of -32 to $35 \%$ was postulated for the sulphur bacteria (Conway et al. 1989). This value is rather conservative considering the 
average values of $-30 \%$ to $-42(-47 \%$ ) for sulphurbased chemoautotrophic symbioses given by Brooks et al. (1987) and Cary et al. (1989). According to our calculations the annelid tissue in the symbiosis of $I$. leukodermatus would then have a $\delta^{13} \mathrm{C}$ of -23 to $-24 \%$. These values are more negative than the isotope ratios of photosynthetically based carbon sources in benthic animals, which range between -15 and $-21 \%$, or of dissolved inorganic carbon in sediment pore water ( +18 to $-20 \%$; Paull et al. 1985 , Southward 1987). Hence, they suggest a dominant nutritive role for the chemosynthetic bacterial symbionts of these gutless worms. Dando et al. (1986) inferred from $\delta^{13} \mathrm{C}$ values of -23.4 to 35.3 in some symbiotic pogonophorans and bivalves a supply of $50 \%$ or more through fixation by their endosymbionts.

Nitrogen stable isotope ratios cover a wide range in animals as the $\mathrm{N}$-ratio is altered during trophic transfers, usually increasing the ${ }^{15} \mathrm{~N}$ content each time by 3 to $5 \%$ (Minagawa \& Wade 1984, Paull et al. 1985, Peterson \& Fry 1987). The ratio recorded in Inanidrilus leukodermatus $(-1.4 \%)$ is clearly lower than that found in tissues derived from photosynthetic-based food chains ( +1 to +20 ; Paull et al. 1985), and also lower than in most organisms (except mussels) from the Galapagos and $21^{\circ} \mathrm{N}$ hydrothermal vents, including annelids (Rau 1985, Fisher et al. 1988). This range indicates that the organic matter of the worms is not likely to be derived from a phytoplankton-based food chain, but is largely dependent on unusually depleted $\mathrm{N}$ sources. In the absence of geothermal vents these values suggest that much of the nitrogen in the symbiosis may orginate from bacterial nitrogen fixation or other bacterial N-metabolic processes (Rau 1985).

It is conceivable that the symbiosis has access to and assimilates a very large supply of bacteria-mediated ammonia or nitrate. Indeed, ammonia values of $980 \mu \mathrm{mol} \mathrm{g}^{-1}$ dry wt of annelid tissue were measured. For interstitial water analyzed in cores from the sampling area, values in the range of $100 \mu \mathrm{mol} \mathrm{dm}^{-3}$ with maxima $>700 \mu \mathrm{mol} \mathrm{dm}{ }^{-3}$ were not unusual (Liebezeit unpubl.). Felbeck et al. (1983) showed the presence of substantial nitrate reductase activity in Inanidrilus leukodermatus.

Amino acids. The interesting point in these analyses is the presence of the complete set of amino acids in these gutless worms, with the essential ones accounting for about $50 \%$ of the total. Many chemoautotrophic bacteria, e.g. Thiomicrospira crunogena, can produce all the essential amino acids (Conway 1990). Also, Trytek \& Allen (1980) demonstrated the synthesis of essential amino acids by the prokaryotic symbionts of the shipworm Bankia setacea (Bivalvia) and the inability of the host alone to synthesize them. Hence, it could be concluded that $I$. leukodermatus also derives its supply of these substances from its bacterial symbionts. Perhaps the unusually low nitrogen stable isotope fractionation, demonstrated above, is a good indication of the prokaryotic origin of many amino acids.

On the other hand, it cannot be excluded that the worms take up (parts of) their supply of amino acids directly from the high concentrations of amino acids dissolved in the ambient pore water. Compared to the seawater $3 \mathrm{~cm}$ above the sediment surface, the pore water of the sampling area was about 50 to 60 times enriched in free dissolved amino acids. In the $5 \mathrm{~cm}$ sediment-horizon (a depth of regular worm occurrence) concentrations in the range of several hundred $\mu \mathrm{M} \mathrm{I}^{-1}$ have been measured (analyses performed in 1981 by Liebezeit unpubl.). Although the analytical methods differed from those used here for tissue analysis, the percentage relation of amino acids in the pore water of 3 sediment cores monitored can be compared (see Table 1). Here too, the complete set of amino acids could be recorded; however, in the pore water almost half the amount is made up by glutamic acid, while essential amino acids accounted for only $15 \%$ of the total. Particularly valine and leucine were present in much lower relative concentrations (mostly $<1 \%$ each) than in the annelid homogenate containing bacteria (Table 1). Thus, the difference in many amino acids can result either (and rather improbably) from a 10 -fold enrichment accomplished by selective uptake of the annelids or from the metabolism of their endosymbiotic prokaryonts.

Lipids. Although based on just 3 extractions from one pooled worm sample, the overall percentage relation of lipids is probably representative, even though the samples could not be analyzed immediately nor kept frozen. The large amount of unsaturated fatty acids indicates that oxidation has not occurred. With the high ratio of one specific bacterial lipid (cis-vaccenic acid) the spectrum of lipids underlines the metabolic role the prokaryonts play in the symbiosis with the anenteric annelid. This mono-unsaturated fatty acid is often the major end product of a bacterial pathway in the absence of oxygen, with $16: 1 \omega 7$ produced as a secondary product (Goldfine 1972, Fulco 1983). This could be interpreted as another indication for the regular occurrence of Inanidrilus leukodermatus in completely anoxic layers where its bacteria not only can take up sulphide but also can drive an active anaerobic metabolism. Similarly high amounts of cis-vaccenic acid have been found in cultures of free-living sulphur bacteria. In Solemya velum, the only animal-bacteria symbiosis where the lipid composition is published, the relative amount of this bacterial lipid was much lower (Conway \& McDowell Capuzzo 1990a, b), but still remarkably high in comparison with other marine species. Thus, this lipid probably reflects utilization of 
bacterial lipid metabolites. I. leukodermatus, like S. velum, contains only a small amount of highly unsaturated fatty acids in contrast to most non-symbiotic marine animals (compare Conway \& McDowell Capuzzo $1990 \mathrm{~b})$. Although $\delta^{13} \mathrm{C}$ ratios of fatty acids have not been measured, it can be concluded that in this mouthless worm the pattern of lipids is symbiontbased reflecting the strong metabolic influence of its endobacteria. Palmitic acid and stearic acid, the 2 other dominating amino acids in I. leukodermatus $(23 \%$ of total; see Fig. 9), are preferred substrates utilized in normal, aerobic pathways.

In this context, the rich amounts of the bacterial reserve substance polyhydroxy butyric acid ( $2 \%$ of the total dry wt of the worm; Giere et al. 1988a) should be stressed.

\section{CONCLUSIONS}

Our earlier studies on the structure (Giere \& Langheld 1987), physiology (Felbeck et al. 1983, Liebezeit et al. 1983), microbiology (Giere et al. 1988b) and field ecology (Giere et al. 1982) all underline the relevance of the prokaryotic symbionts for the nutrition of the gutless Inanidrilus leukodermatus. In this study, ecological experimentation has shown that the bacterial metabolic needs, which depend on a particular physicochemical regime, dominate the system and, in this sense, 'regulate' the microdistribution of their annelid hosts. Biochemical analyses corroborated our conclusions from ecological results. Bacterial 'biomarkers' showed the substantial input of bacterial chemoautotrophy to the trophic needs of the worms.

The mutualistic role of the annelid hosts for the prokaryonts in this obligate symbiosis is underlined by the migration experiments. In a spatially complex, temporally variable gradient system of oxygen and sulphur compounds, the bacteria become adjusted by the worms to the appropriate milieu, enabling them to maintain an effectively high metabolic level. If a migratory behaviour of mobile thiobios, both bacteria-symbiotic and asymbiotic, over a range of changing oxygen and sulphide gradients (including extended stays in layers of complete anoxia) can be generalized (Meyers et al. 1988, Ott \& Novak 1989), it may explain many of the controversial views on a meiobenthic thiobios which arose from the limited ecological and physiological understanding of animal life in sulphide-based ecosystems at that time (Reise \& Ax 1979, Boaden 1980, Powell \& Bright 1981).

The tight metabolic, ecological and structural coupling between bacteria and animal host shown in our studies on Inanidrilus leukodermatus represents an evolutionary potential apparently powerful and advan- tageous enough to allow for the complete loss of digestive and excretory organs. Regarding the high number of gutless phallodriline tubificids (ca 100 mostly undescribed species; Erséus pers. comm.) probably all in symbiosis with endobacteria, this trend seems more than just an isolated evolutionary event. It renders these oligochaetes favourable objects for further studies on the evolution of animal-bacteria symbioses.

Acknowledgements. The work in Bermuda was possible through the generous help of the Bermuda Aquarium, Museum and Zoo providing us with lab space, instruments and boats. We are particularly indebted to Dr W. Sterrer, Curator of the Bermuda Museum, to Ms D. Westphalen and Mr 'Billy' Mitchell (Bermuda) for their valuable assistance in diving and sampling the worms. Stable isotope analyses were performed in the laboratory of Dr B. Fry, MBL Ecosystems Center, Woods Hole, USA, which is gratefully acknowledged. Thanks are due to Dr A. Ribowski (Hamburg) for his advice on computer-supported statistical treatment of the data. The senior author thanks the Deutsche Forschungsgemeinschaft for financial support (Gi 100/8-4). Woods Hole Oceanographic Institution Contribution no. 7392.

\section{LITERATURE CITED}

Arp, A. J., Childress, J. J., Fisher, C. R. (1984). Metabolic and blood gas transport characteristics of the hydrothermal vent bivalve Calyptogena magnifica. Physiol. Zool. 57: 648-662

Boaden, P. J. S. (1980). Meiofaunal thiobios and 'the Arenicola negation': case not proven. Mar. Biol. 58: 25-29

Böttcher, J., Strebel, O. (1985). Redoxpotential und Eh/pHDiagramme von Stoffumsetzungen in reduzierendem Grundwasser (Beispiel Fuhrberger Feld). Geol. Jb. C 40: 3-34

Brooks, J. M., Kennicutt, M. C., Fisher II, C. R., Macko, S. A., Cole, K., Childress, J. J., Bidigare, R. R., Vetter, R. D. (1987). Deep-sea hydrocarbon seep communities: evidence for energy and nutritional carbon sources. Science 238: 1138-1142

Burgh, M. E. de (1986). Evidence for a physiological gradient in the vestimentiferan trophosome: size-frequency analysis of bacterial populations and trophosome chemistry. Can. J. Zool. 64: 1095-1103

Cary, C., Fry, B., Felbeck, H., Vetter, R. D. (1989). Multiple trophic resources for a chemoautotrophic community at a cold water brine seep at the base of the Florida Escarpment. Mar. Biol. 100: 411-418

Cavanaugh, C. M. (1985). Symbiosis of chemoautotrophic bacteria and marine invertebrates from hydrothermal vents and reducing sediments. Bull. Biol. Soc. Wash. 6: 373-388

Cline, J. D. (1969). Spectrophotometric determination of hydrogen sulfide in natural waters. Limnol. Oceanogr. 14: $454-458$

Conway, N. (1990). The role of endosymbiotic bacteria in animal-bacteria symbioses. Solemya velum, a case study. $\mathrm{Ph}$. D. thesis, Mass. Inst. Technol./Woods Hole Oceanogr. Instn

Conway, N., McDowell Capuzzo, J. (1990a). The use of biochemical indicators in the study of trophic interactions in animal-bacteria symbioses: Solemya velum, a case 
study. In: Barnes, M., Gibson, R. N. (eds.) Trophic relationships in the marine environment. Proc. 24th Eur. Mar. Biol. Symp. Aberdeen Univ. Press, Aberdeen, p. 553-564

Conway, N., McDowell Capuzzo, J. (1990b). Incorporation and utilization of bacterial lipids by the Solemya velum symbiosis. Mar. Biol. (in press)

Conway, N., McDowell Capuzzo, J., Fry, B. (1989). The role of endosymbiotic bacteria in the nutrition of Solemya velum: evidence from a stable isotope analysis of endosymbionts and host. Limnol. Oceanogr. 34: 249-255

Dando, P. R., Southward, A. J., Southward, E. C., Barrett, R. L. (1986). Possible energy sources for chemoautotrophic prokaryotes symbiotic with invertebrates from a Norwegian fjord. Ophelia 26: 135-150

Felbeck, H., Liebezeit, G., Dawson, R., Giere, O, (1983). $\mathrm{CO}_{2}$ fixation in tissues of marine oligochaetes (Phallodrilus leukodermatus and $P$. planus) containing symbiotic, chemoautotrophic bacteria. Mar. Biol. 75: 187-191

Feller, R. J., Warwick, R. M. (1988). Energetics. In: Higgins, R. P., Thiel, H. (eds.) Introduction to the study of meiofauna. Smithsonian Institution Press, Washington, D.C., p. 181-196

Fisher, C. R., and 14 others (1988). Microhabitat variation in the hydrothermal vent mussel, Bathymodiolus thermophilus, at the Rose Garden vent on the Galapagos Rift. Deep Sea Res. 35: 1769-1791

Fox, C. A., Powell, E. N. (1987). The effect of oxygen and sulfide on $\mathrm{CO}_{2}$ production by three acoel turbellarians. Are thiobiotic meiofauna aerobic? Comp. Biochem. Physiol. 86 A: 509-514

Fulco, A. J. (1983). Fatty acid metabolism in bacteria. Prog. Lipid Res. 22: 133-160

Gardner, L. R. (1973). The effect of hydrologic factors on the pore water chemistry of intertidal marsh sediments. Southeast. Geol. 15: 17-28

Gardner, L. R., Wolaver, T. G., Mitchell, M. (1988). Spatial variations in the sulfur chemistry of salt marsh sediments at North Inlet, South Carolina, J. mar. Res. 46: 815-836

Giere, O. (1989). The first annual Riser lecture: meiofauna and microbes - the interactive relations of annelid hosts with their symbiotic bacteria. Proc. Biol. Soc. Wash. 102: $109-115$

Giere, O., Eleftheriou, A., Murison, D. J. (1988a). Abiotic factors. In: Higgins, R. P., Thiel, H. (eds.) Introduction to the study of meiofauna. Smithsonian Institution Press, Washington, D.C., p. 61-78

Giere, O., Felbeck, H., Dawson, R., Liebezeit, G. (1984). The gutless oligochaete Phallodrilus leukodermatus Giere, a tubificid of structural, ecological and physiological relevance. Hydrobiologia 115: 83-89

Giere, O., Langheld, C. (1987). Structural organization, transfer and biological fate of endosymbiotic bacteria in gutless oligochaetes. Mar. Biol. 93: 641-650

Giere, O., Liebezeit, G., Dawson, R. (1982). Habitat conditions and distribution pattern of the gutless oligochaete Phallodrilus leukodermatus. Mar. Ecol. Prog. Ser. 8: 291-299

Giere, O., Wirsen, C. O., Schmidt, C., Jannasch, H. W. (1988b). Contrasting effects of sulfide and thiosulfide on symbiotic $\mathrm{CO}_{2}$-assimilation of Phallodrilus leukodermatus (Annelida). Mar. Biol. 97: 413-419

Goldfine, H. (1972). Comparative aspects of bacterial lipids. Adv. Microb. Physiol. 8: 1-58

Howes, B. L., Wakeham, S. G. (1985). Effects of a sampling technique on measurements of porewater constituents in salt marsh sediments. Limnol. Oceanogr. 30: 221-227

Jørgensen, B. B., Revsbech, N. P. (1983). Colorless sulfur bacteria Beggiatoa spp. and Thiovolum spp., in $\mathrm{O}_{2}$ and $\mathrm{H}_{2} \mathrm{~S}$ microgradients. Appl environ. Microbiol. 45: 1261-1270

Liebezeit, G., Felbeck, H., Dawson, R., Giere, O. (1983). Transepidermal uptake of dissolved carbohydrates by the gutless marine oligochaete Phallodrilus leukodermatus (Annelida). Océanis 9: 205-211

Meyers, M. B., Fossing, H., Powell, E. N. (1987). Microdistribution of interstitial meiofauna, oxygen and sulfide gradients, and the tubes of macro-infauna. Mar. Ecol. Prog. Ser. 35: 223-241

Meyers, M. B., Powell, E. N., Fossing, H. (1988). Movement of oxybiotic and thiobiotic meiofauna in response to changes in pore-water oxygen and sulfide gradients around macroinfaunal tubes. Mar. Biol. 98: 395-414

Minagawa, M., Wada, E. (1984). Stepwise enrichment of ${ }^{15} \mathrm{~N}$ along food chains: further evidence for the relation between $\delta^{15} \mathrm{~N}$ and animal age. Geochim. Cosmochim. Acta 48: $1135-1140$

Ott, J. A., Novak, R. (1989). Living at an interface: meiofauna at the oxygen/sulfide boundary of marine sediments. In: Ryland, J. S., Tyler, P. A. (eds.) Reproduction, genetics and distributions of marine organisms. 23rd Eur. Mar. Biol. Symposium. Olsen \& Olsen, Fredensborg, p. 415-422

Paull, C. K., Jull, A. J. T., Toolin, L. J., Linick, T. (1985). Stable isotope evidence for chemosynthesis in an abyssal seep community. Nature, Lond. 317: 709-711

Peterson, B. J., Fry, B. (1987). Stable isotopes in ecosystem studies. A. Rev. Ecol. Syst. 18: 293-320

Powell, E. N. (1989). Oxygen, sulfide and diffusion: why thiobiotic meiofauna must be sulfide-insensitive first-order respirers. J. mar. Res. 47: 887-932

Powell, E. N., Bright, T. J. (1981). A thiobios does exist Gnathostomulid domination of the Canyon community at the East Flower Garden brine seep. Int. Revue ges. Hydrobiol. 66: 675-683

Powell, E. N., Bright, T. J., Woods, A., Gittings, S. (1983). Meiofauna and the thiobios in the East Flower Garden brine seep. Mar. Biol. 73: 269-283

Powell, M. A., Arp, A. J. (1989). Hydrogen sulfide oxidation by abundant nonhemoglobin heme compounds in marine invertebrates from sulfide-rich habitats. J. exp. Zool. 249: 121-132

Rau, G. H. (1985). ${ }^{13} \mathrm{C} /{ }^{12} \mathrm{C}$ and ${ }^{15} \mathrm{~N} /{ }^{14} \mathrm{~N}$ in hydrothermal vent organisms: ecological and biogeochemical implications. Biol. Soc. Wash. Bull. 6: 243-247

Reid, R. G. B., Brand, D. G. (1986). Sulfide-oxidizing symbiosis in lucinaceans: implications for bivalve evolution. Veliger 29: $3-24$

Reise, K., Ax, P. (1979). A meiofaunal 'thiobios' limited to the anaerobic sulfide system of marine sand does not exist. Mar. Biol. 54: 225-237

Rounick, J. S., Winterbourn, M. J. (1986). Stable carbon isotopes and carbon flow in ecosystems. BioScience 36: 171-177

Scherer, B. (1985). Annual dynamics of a meiofauna community from the 'sulfide layer' of a North Sea sand flat. Microfauna Mar. 2: 117-161

Southward, E. C. (1987). Contribution of symbiotic chemoautotrophs to the nutrition of benthic invertebrates. In: Sleigh, M. A. (ed.) Microbes in the sea. Wiley \& Sons, New York, p. 83-118

Spiro, B., Greenwood, P. B., Southward, A. J., Dando, P. R. $(1986),{ }^{13} \mathrm{C} /{ }^{12} \mathrm{C}$ ratios in marine invertebrates from reducing sediments: confirmation of nutritional importance of chemoautotrophic endosymbiotic bacteria. Mar. Ecol. Prog. Ser. 28: 233-240

Stephens, G. C. (1975). Uptake of naturally occuring primary 
amins by marine annelids. Biol. Bull. mar. biol. Lab., Woods Hole 149: 397-407

Trytek, R. E., Allen, W. V. (1980). Synthesis of essential amino acids by bacterial symbionts in the gills of the shipworm Bankia setacea (Tryon). Comp. Biochem. Physiol. 67 A: 419-427

Weber, R. E. (1978). Respiratory pigments. In: Mill, P. J. (ed.)

This article was submitted to the editor
Physiology of annelids. Academic Press, London, p. 393-446

Yang, C.-Y., Sepulveda, F. I. (1985). Separation of phenylthiocarbamyl amino acids by high-performance liquid chromatography on Spherisorb octadecylsilane columns. J. Chromatogr. 346: 413-416

Manuscript first received: May 21, 1990

Revised version accepted: August 31, 1990 